\title{
Characterization and Localization of Plasmid Functions Involved in Pock Formation and Pock Resistance of Plasmid pSK3* of Streptomyces kasugaensis MB273
}

\author{
By HISA YOSHI AKAGA WA \\ Department of Antibiotics. The National Institute of Health. 10-35 Kamiosaki 2-Chome. \\ Shinagawa-Ku. Tokyo. 141, Japan
}

(Receired 15 October 1986; revised 23 January 1987)

\begin{abstract}
Deletion derivatives and recombinants of the plasmid $\mathrm{pSK} 3^{*}$, which is a cointegrate of $\mathrm{pSK} 1^{*}$ and pSK2* in Streptomyces kasugaensis, were constructed and analysed for their ability to transfer and 'pock' on strains carrying $\mathrm{pSK} 1^{*}$ or $\mathrm{pSK} 2^{*}$. Various deletions in the $\mathrm{pSK} 1^{*}$ and/or pSK 2* regions of pSK $3^{*}$ were grouped into nine classes on the basis of their pock-forming ability and pock resistance. Analysis of these deletions and insertions provided tentative locations of DNA regions for two pock-resistance determinants (Por 1 and Por2), two pockforming determinants (Poc1 and Poc2) consisting of plasmid transfer and spread determinants (Tra/Spr), and two replication determinants (Repl and Rep2) corresponding to the pSK $1^{*}$ and pSK2* regions of pSK $3^{*}$. In particular, the Por 2 function in the pSK2* region was determined to be located in a $1.35 \mathrm{~kb}$ segment.
\end{abstract}

\section{INTRODUCTION}

Several conjugative Streptomyces plasmids cause inhibition of growth or differentiation when colonies or patches of a plasmid-containing culture are grown on a lawn of a plasmid-free strain on solid media. This inhibition of the plasmid-free strain. or 'pocking', appears to be associated with plasmid transfer, and has been suggested to be analogous to the 'lethal zygosis' phenomenon shown by some Escherichia coli plasmids (Bibb et al., 1977). In some Streptomyces plasmids the ability to cause easily visible pocks arises only in spontaneous plasmid variants, as in the isolation of SCP2* mutants of the Streptomyces coelicolor plasmid SCP2 (Bibb et al., 1977; Bibb \& Hopwood, 1981). In addition to carrying the functions for transfer and spread, these plasmids also determined resistance to their own pock-forming activity. These functions have been described and tentatively localized on the restriction maps for pIJ101 in Streptomyces lividans (Kieser et al., 1982) and for SCP2* in S. coelicolor A3(2) (Lydiate et al., 1985). The mechanisms of pock formation and resistance have not yet been elucidated.

Streptomyces kasugaensis MB273 carries three plasmids, pSK1, pSK2 and pSK3. 'Pocking' mutants of all three have been isolated, pSK 1*, pSK2* and pSK 3* (Akagawa et al., 1984, 1987). pSK $3^{*}$ has been shown to be a cointegrate of pSK ${ }^{*}$ and pSK2* (Akagawa et al., 1987). Here we describe the construction and analysis of deletion derivatives of pSK $3^{*}$ which showed changes in functions concerning pock formation and/or pock resistance to strains harbouring pSK $1^{*}$ and pSK $2^{*}$, allowing localization of these functions. These deletions are compared to recombinant plasmids constructed between $\mathrm{pSK} \mathrm{I}^{*}$ and $\mathrm{pSK} 2^{*}$.

\section{METHODS}

Bacterial strains and media. The origins of the Streptomyces kasugaensis MB273 derivatives used are described in the accompanying paper (Akagawa et al., 1987): AlR6 (prototroph), R6N1 (Mal-) and R6N2 (His ${ }^{-}$) (plasmidfree strains), R6N1(pSK 1*), R6N2(pSK1*), R6N1(pSK2*), R6N2(pSK2*) and R6N2(pSK 3*). Strains of R6N1 
and R6N2 carrying a pSK $3^{*}$ derivative were isolated from pocks produced by strains carrying the plasmid on lawn cultures of strains R6N1 and R6N2. GMY and MM agar media, GIPYG medium for submerged cultivation, and R3 medium for protoplast regeneration, were described previously (Akagawa et al., 1984). MM was supplemented, if necessary, with histidine $\left(50 \mu \mathrm{g} \mathrm{ml}^{-1}\right)$ or glucose $(1 \%, \mathrm{w} / \mathrm{v})$ instead of maltose.

Plasmid DNA preparation, restriction endonuclease digestion, DNA ligation and agarose gel electrophoresis. These methods were as described previously (Akagawa et al., 1984, 1987).

Pock formation and detection of plasmids of strains and colonies isolated from pocks. The methods were those described previously (Akagawa et al., 1984).

Preparation and regeneration of protoplasts and transformation. The methods for preparation and regeneration of S. kasugaensis protoplasts and detection of transformants were those described previously (Akagawa et al., 1984). Transformation was done as described by Akagawa et al. (1987).

Determination of plasmid transfer in pock formation. Plasmid transfer from strains containing a donor plasmid to strains carrying pSK $1^{*}, \mathrm{pSK} 2^{*}$ or neither plasmid coincident with pock formation was detected as follows. Strain R6N2 (His ${ }^{-}$) carrying a donor plasmid was crossed with strain R6N1 (Mal-) carrying pSK ${ }^{*}$, pSK2* or neither plasmid to induce pocks on the lawn of the latter strains. Spores/mycelium in a pock area were picked with toothpicks and suspended in a small volume of water. These suspensions were spread on GMY plates and incubated. When well grown, colonies were replica plated on diagnostic plates. Almost all the colonies (200-2000 per pock) had the $\mathrm{Mal}^{-}$phenotype identical with that of the lawn culture. Some of these $\mathrm{Mal}^{-}$colonies were examined for plasmid content by the methods described previously (Akagawa et al., 1984).

\section{RESULTS}

\section{Construction of pock-forming deletion derivatives of $p S K 3^{*}$ and recombinant plasmids between $p S K 1^{*}$ and $p S K 2^{*}$}

In order to map pock-forming and pock-resistance functions of the pSK $3^{*}$ plasmid, various pock-forming deletion derivatives were constructed. The deletion derivative pSK3*-D3 (Akagawa et al., 1987) was digested completely or partially with $B a m H I, B c l I, B g l$ II, EcoRI, $K p n I$ or $S a c I$, and ligated. The following seven deletion derivatives were obtained after selfligation of the above digests: D311 $(14.8 \mathrm{~kb})$ from the $B c l$ I digest; D312 (14.2 kb) and D313 $(17.7 \mathrm{~kb})$ from the $B g / \mathrm{II}$ digest; D314 $(17.0 \mathrm{~kb})$ and D315 (12.3 kb) from the KpnI digest; D316 $(16.2 \mathrm{~kb})$ and D317 $(13.5 \mathrm{~kb})$ from the SacI digest. Two deletion derivatives [D3141 (10.8 kb) and D3171 (11.3 kb)] were constructed by self-ligation of the $\mathrm{Bcl}$ I digest of D314 and the SacI digest of D317, respectively. Their restriction endonuclease cleavage maps are shown in Fig. 1. Six other pock-forming derivatives of $\mathrm{pSK} 3^{*}$ with spontaneous deletions were obtained in selfligations similar to those described above: D321 (11.7 kb) was obtained from a BamHI digest, D322 $(12.9 \mathrm{~kb})$, D323 $(15.3 \mathrm{~kb})$ and D324 $(14.0 \mathrm{~kb})$ from an EcoRI digest, D325 (15.6 kb) from a KpnI digest, and D326 $(11.8 \mathrm{~kb})$ from a SacI digest. As shown in Fig. 1, these pSK $3{ }^{*}$ derivatives lacked DNA segments not readily explained by the action of the restriction endonucleases used.

Recombinant plasmids were constructed by in vitro recombination between $\mathrm{pSK} 1^{*}$ and pSK2*. As shown in Fig. 1, pSK1* cut with $B c l$ I was inserted into two $B c l$ I sites of pSK2* (corresponding to sites 16 or 23 in the pSK2* part of $\mathrm{pSK} 3^{*}$ ) to give recombinant plasmids pSK1-2R $1^{*}$ and pSK1-2R2*, respectively. pSK $1^{*}$ cut with $B c l$ I was also inserted into two Bam HI sites of pSK 2* (corresponding to sites 24 or 25 in the pSK $2^{*}$ part of pSK $3^{*}$ ) with deletion of the small intervening fragment from pSK2* to give the recombinant pSK1-2R3*. The integration site and orientation of $\mathrm{pSK} 1^{*}$ in these three recombinant plasmids, pSK $1-2 \mathrm{R} 1^{*}$, pSK $1-2 R 2^{*}$ and pSK $1-2 R 3^{*}$, was determined by single digestion with $B c l$ I, Bam HI, BglII and EcoRI. The pSK $1^{*}$ insertion had the same orientation in all three constructions.

\section{Changes in pock-forming ability and pock resistance correlating with deletions of pSK3* and insertion of $\mathrm{pSK1^{* }}$ into $\mathrm{pSK2} 2^{*}$}

The pSK 3* derivatives and the recombinant plasmids between $\mathrm{pSK} 1^{*}$ and $\mathrm{pSK} 2^{*}$ were characterized for their pock-forming ability and resistance to pock forming by $\mathrm{pSK} \mathrm{I}^{*}$ and pSK2*, as shown in Fig. 1. Based on their pock-forming ability and pock resistance, the pSK3* deletion derivatives, and strains bearing them, were grouped into nine classes. 

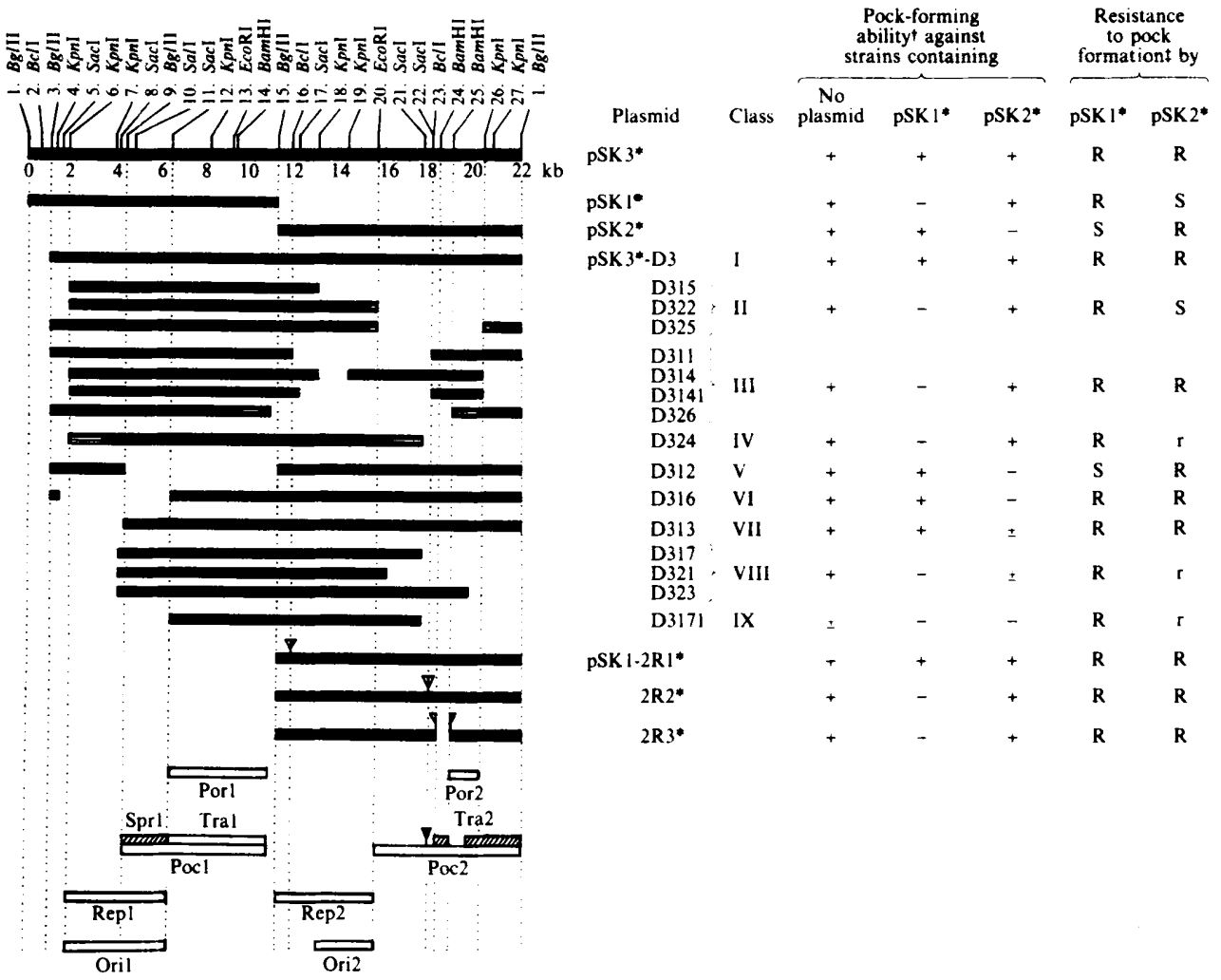

Fig. 1. Physical structure of deletion derivatives of $\mathrm{pSK} 3^{*}$ and recombinant plasmids of $\mathrm{pSK} 1^{*}$ and $\mathrm{pSK} 2^{*}$, their pock-forming ability, their resistance to pock formation by $\mathrm{pSK} 1^{*}$ and $\mathrm{pSK} 2^{*}$, and tentative locations of plasmid functions on pSK $3^{*}$.

, DNA region maintained; $\longrightarrow$ DNA region possibly maintained; $\nabla$, insertion site of pSK $1^{*}$. Region containing the function; the function; $Y$, insertion site of $\mathrm{pSK} 1^{*}$ resulting in loss of the function.

Pocl and Poc2, the functions for pock formation of the $\mathrm{pSK} 1^{*}$ and $\mathrm{pSK} 2^{*}$ parts of $\mathrm{pSK} 3^{*}$, respectively; Porl and Por2, the functions for pock resistance of the pSK $1^{*}$ and pSK 2* parts of pSK $3^{*}$, respectively; Repl and Rep2, the functions for plasmid replication of the pSK1* and pSK2* parts of $\mathrm{pSK} 3^{*}$, respectively; Spr 1, the function for plasmid spread of the pSK $1^{*}$ part of $\mathrm{pSK} 3^{*}$; Tral and Tra2, the functions for plasmid transfer of the pSK $1^{*}$ and pSK2* parts of $\mathrm{pSK} 3^{*}$, respectively. Oril and Ori2 are the regions necessary for plasmid replication and stability of pSK 1 and $\mathrm{pSK} 2$, respectively, determined by Nabeshima et al. (1984).

$\dagger+$, Induced regular-size pocks; - , induced no pocks; \pm , induced small pocks.

$\ddagger \mathbf{R}$, resistance to pock formation by $\mathrm{pSK} 1^{*}$ or $\mathrm{pSK} 2^{*}$ (strains containing $\mathrm{pSK} 1^{*}$ or $\mathrm{pSK} 2^{*}$ induced no pock on the lawns of the strain carrying the deletion derivative); $S$, sensitive to pock formation by pSK2* or pSK $1^{*}$ (strains containing $\mathrm{pSK} 2^{*}$ or $\mathrm{pSK} 1^{*}$ induced regular pocks on lawns of the strain carrying the deletion derivative); $r$, weak resistance to pock formation by pSK $2^{*}$ (strains containing pSK2* induced small pocks on lawns of the strain carrying the deletion derivative.

pSK 3*-D3 (class I) was indistinguishable from pSK $3^{*}$ in terms of pock formation and pock resistance, indicating that the $B g l I I(1)-B g l I I(3)$ region is not involved in any known function of pSK 3*.

Class II strains, carrying D315, D322 and D325, which all lack the EcoRI(20)-KpnI(26) segment of the pSK $2^{*}$ part of pSK $3^{*}$, were deficient in pock formation on lawns carrying $\mathrm{pSK} 1^{*}$ and were sensitive to pock formation by pSK $2^{*}$. They were thus indistinguishable from pSK ${ }^{*}$ in their pock-forming ability and pock resistance.

Class III strains, carrying D311, D314, D3141 and D326, which have deletions in the pSK2* part of pSK $3^{*}$ but retain part or all of the Bam HI(25)-KpnI(26) region, showed the same pock- 


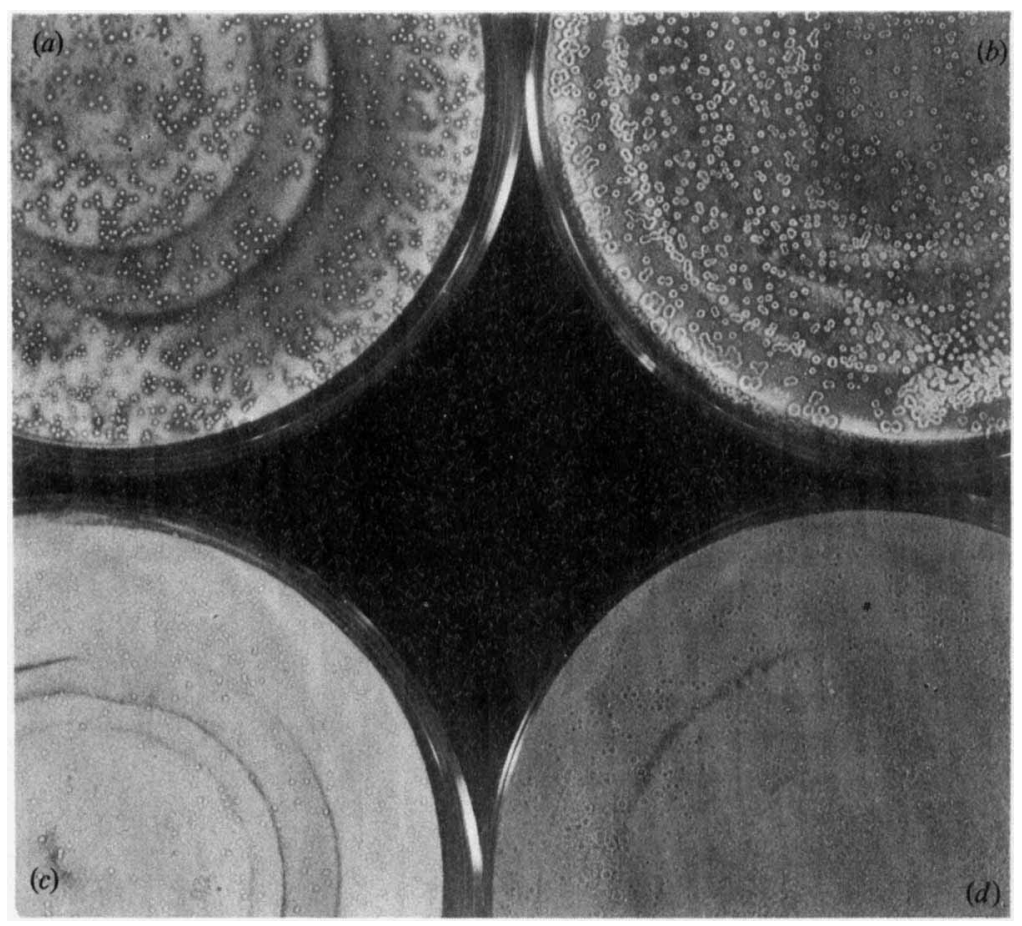

Fig. 2. Appearance of small pocks in crosses between strains carrying D317 and strains carrying pSK $2 *$. (a) Small pocks produced by a D317 donor on a pSK2* lawn; (b) regular pocks produced by a D317 donor on a plasmid-free lawn; $(c)$ small pocks produced by a pSK2* donor on a D317 lawn; $(d)$ regular pocks produced by a $\mathrm{pSK} 2^{*}$ donor on a plasmid-free lawn.

forming ability as that of class II strains. However, they were resistant to pock formation by pSK2*, whereas class II strains were sensitive.

The one class IV strain, carrying D324, which had a deletion in the pSK2* part of pSK $3^{*}$ but retained the whole $B g / \mathrm{II}(9)-E c o \mathrm{RI}(20)$ region, showed the same pock-forming ability as class II strains but differed from them in its weak pock resistance to $\mathrm{pSK} 2^{*}$. pSK $2^{*}$-containing strains did not induce regular pocks on lawns of the class IV strain but showed small pocks.

Strains containing class V (D312), VI (D316) and VII (D313) plasmids, which have deletions in the $\mathrm{pSK} 1^{*}$ part of $\mathrm{pSK} 3^{*}$, retained $\mathrm{pSK} 2^{*}$ functions (i.e. pock-forming ability against the $\mathrm{pSK} 1^{*}$-containing strain and pock resistance to the $\mathrm{pSK} 2{ }^{*}$-containing strain). However, they differed from each other in their $\mathrm{pSK} 1^{*}$ functions. Class $\mathrm{V}$ neither induced pocks against the pSK2*-containing strain nor resisted pock formation by the $\mathrm{pSK} 1^{*}$ strain. Class VI differed from class $\mathrm{V}$ in showing resistance to pocking by $\mathrm{pSK} \mathrm{I}^{*}$. Class VII differed from classes $\mathrm{V}$ and $\mathrm{VI}$ in showing small pocks against the $\mathrm{pSK} 2^{*}$-containing strain.

Strains containing class VIII (D317, D321 and D323) and IX (D3171) plasmids, which have deletions in both the $\mathrm{pSK} 1^{*}$ and the $\mathrm{pSK} 2^{*}$ parts of $\mathrm{pSK} 3^{*}$, showed pock-forming activity and pock resistance different from those of strains containing the other classes of pSK $3^{*}$ derivatives. Obvious changes were observed in pock-forming activity and pock resistance due to the pSK2* part of pSK $3^{*}$ and pock-forming activity due to the pSK $1^{*}$ part of pSK $3^{*}$. Class VIII plasmids were similar to class VII but different in pSK2* functions for pock formation and pock resistance (i.e. these plasmids did not form pocks against the pSK 1 *-containing strain but showed small pocks against the pSK2*-containing strain). Small pocks induced by a D317containing strain on a lawn of the strain carrying pSK2* and by a pSK $2^{*}$-containing strain on the lawn of a strain carrying D317 are shown in Fig. 2. Class IX was unique in induction of small pocks on lawns of a plasmid-free strain. 


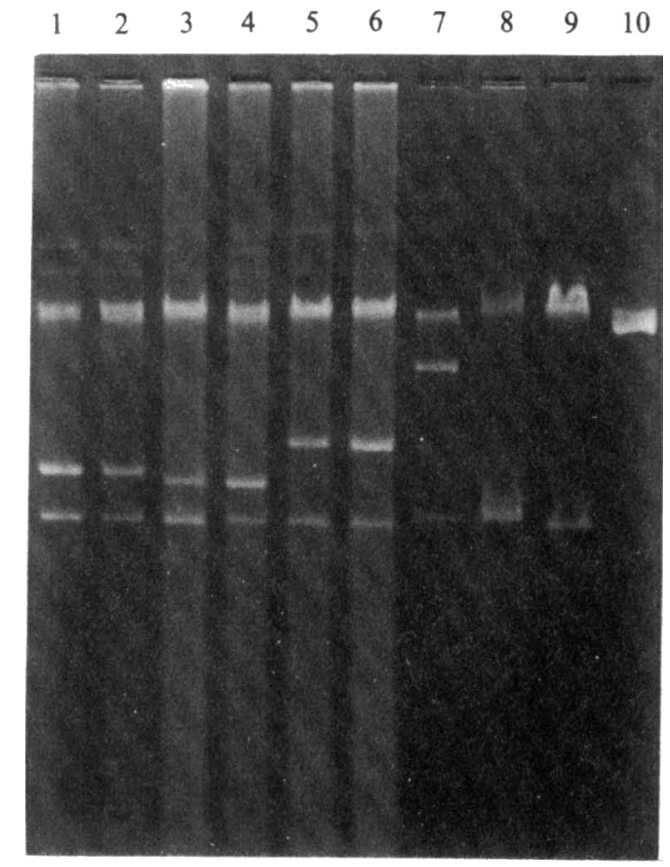

Fig. 3. Agarose gel electrophoresis of plasmids in crude extracts of cultures of $\mathrm{R} 6 \mathrm{~N} 1\left(\mathrm{Mal}^{-}\right)$recipient colonies derived from pocks induced by R6N2 ( $\mathrm{His}^{-}$) donor strains carrying a different plasmid from that carried by the recipient strain. 1, Plasmids from a pock by R6N2(D322) on an R6N1(pSK2*) lawn; 2, plasmids from a pock by R6N2(pSK2*) on an R6N1(D322) lawn; 3, plasmids from a small pock by R6N2(D321) on an R6N1(pSK2*) lawn; 4, plasmids from a small pock by R6N2(pSK2*) on an R6NI(D321) lawn; 5, plasmids from a small pock by R6N2(D317) on an R6N1(pSK2*) lawn; 6, plasmids from a small pock by $\mathrm{R} 6 \mathrm{~N} 2\left(\mathrm{pSK} 2^{*}\right.$ ) on an $\mathrm{R} 6 \mathrm{~N} 1(\mathrm{D} 317)$ lawn; 7, plasmids from a pock by R6N2(D313) on an R6N1(pSK1*) lawn; 8, the plasmid from a pSK 1*-containing strain; 9, the plasmid from a pSK $2^{*}$-containing strain: 10 , the plasmid from a pSK $3^{*}$-D3-containing strain.

Recombination between $\mathrm{pSK} 1^{*}$ and $\mathrm{pSK} 2^{*}$, in which $\mathrm{pSK} 1^{*}$ was inserted into $\mathrm{pSK} 2^{*}$, resulted in the loss of the pSK2* function for pock formation when the insertion was in the Bcl I(23) (pSK 1-2R2*) or Bam HI(24/25) (pSK 1-2R3*) sites (Fig. 1). Insertion in the Bcl I(16) site (pSK1-2R1*) showed no effect.

\section{Plasmid transfer coincident with pock formation}

To determine whether plasmid transfer was associated with pock formation by pSK3* derivatives, R6N2 ( $\mathrm{His}^{-}$) strains carrying deletion derivatives (D322, D314, D312, D316, D313, D317, D323 or D3171) were crossed with R6N1 (Mal $\left.{ }^{-}\right)$strains carrying pSK ${ }^{*}$, pSK2* or neither plasmid to induce pocks on lawns of the latter strains. Transfer of pSK $2^{*}$ in small pocks produced by a pSK $2^{*}$-containing $\mathrm{R} 6 \mathrm{~N} 2\left(\mathrm{His}^{-}\right)$strain on lawns of $\mathrm{R} 6 \mathrm{~N} 1\left(\mathrm{Mal}^{-}\right)$strains carrying D31 7 or D323 (class VIII) was also examined. The $\mathrm{Mal}^{-}$(recipient) colonies isolated from pocks always contained the pSK $3^{*}$ derivative from the donor together with the plasmid carried by the recipient strain. Some examples are given in Fig. 3. Thus it was demonstrated that pock formation by these pSK $3^{*}$ derivatives accompanied plasmid transfer, indicating that they maintain the transfer function (Tra).

Regions involved in changes in pock formation and pock resistance

On the basis of phenotypic changes caused by deletion of $\mathrm{pSK} 3^{*}$ segments and insertion of $\mathrm{pSK} 1^{*}$ into $\mathrm{pSK} 2^{*}$, we attempted to determine the DNA regions involved in plasmid functions. From the results with pSK $1^{*}$ and $\mathrm{pSK} 2^{*}$, it was obvious that the pock-forming ability of pSK $3^{*}$ against strains containing $\mathrm{pSK} 1^{*}$ and the pock resistance to $\mathrm{pSK} 2^{*}$ of the $\mathrm{pSK} 3^{*}$-containing 
strain were due to the pSK2* part of $\mathrm{pSK} 3^{*}$. Similarly, the $\mathrm{pSK} 1^{*}$ part of $\mathrm{pSK} 3^{*}$ is responsible for the pock-forming ability of pSK $3^{*}$ against strains containing pSK $2^{*}$ and the pock resistance to $\mathrm{pSK} 1^{*}$ of the pSK $3^{*}$-containing strain. Therefore, pSK $3^{*}$ has two pock-forming determinant regions (Poc1 and Poc2), two pock-resistance determinant regions (Por1 and Por2) and two replication regions (Rep1 and $\operatorname{Rep} 2$ ) derived from $\mathrm{pSK} 1^{*}$ and $\mathrm{pSK} 2^{*}$, respectively.

In the case of pSK2* functions, it was obvious that strains were fully resistant to pock formation by pSK2* only if they retained some part of the Bam HI(25)-KpnI(26) segment. Without this region, class IV, VIII and IX plasmids conferred a weak resistance, but class II conferred no resistance. The former plasmids retained the $B g l I I(15)-E c o R I(20)$ region, but the class II plasmids had lost at least part of it. Therefore, the BglII(15)-EcoRI(20) segment performs a role in pock resistance although it is not so effective as the Bam HI(25)-KpnI(26) segment. According to Nabeshima et al. (1984), the Ori2 region necessary for replication and stability of pSK2 is located in the KpnI(18)-EcoRI(20) segment. Therefore, the contribution of the $B g l I I(15)-E c o R I(20)$ segment in class IV, VIII and IX plasmids in the partial resistance of these plasmids to pock formation by $\mathrm{pSK} 2 *$ would be due to the incompatibility function of this replication region (Rep2) of pSK2*. The Bam HI(25)-KpnI(26) segment can be concluded to contain the region for pock resistance (Por2). On the other hand, the pock-forming ability of pSK $3^{*}$ derivatives to $\mathrm{pSK} 1^{*}$-containing strains was lost when these derivatives had deletions in their pSK2* segments (class II, III, IV, VIII and IX plasmids). The region of deletion causing this loss of function extended from the right side of the Rep2 region (EcoRI(20)) to $B g / \operatorname{II}(1)$, indicating that the pock-forming function of pSK2* (Poc2) is located somewhere in this segment. This result was consistent with those obtained with the insertion of pSK $1^{*}$ into pSK2* at the $B c l I(23)$ and $B a m H I(24 / 25)$ sites shown in Fig. 1. These insertions resulted in the loss of the ability of pSK $2^{*}$ to pock on a pSK $1^{*}$-carrying strain (recombinant plasmids pSK1-2R2* and pSK 1-2R3*).

In the case of the pSK $1^{*}$ functions of pSK3*, only the class $\mathrm{V}$ plasmid (D312)-containing strain was sensitive to pock formation by $\mathrm{pSK} 1^{*}$. This plasmid had a deletion covering the $B g l I I(9)-B g l I I(15)$ fragment. However, strains carrying the class VI (D316) or IX (D3171) plasmids which retained the $S a c I(11)-B g l I I(15)$ segment were resistant to pock formation by pSK 1*. Therefore, it was concluded that the $\operatorname{SacI}(11)-B g l$ II(15) fragment contained the Por 1 region conferring pock resistance. Class V (D312), VI (D316) and IX (D3171) plasmids which lack the $B g l \mathrm{II}(9)-S a c \mathrm{I}(11)$ fragment of $\mathrm{pSK} 3^{*}$ did not induce pocks on lawns of strains carrying pSK2*, while class VII and VIII plasmids which retained this region induced small pocks. Therefore, this region was assumed to be involved in the pock-forming determinant (Poc1). The small pock formation by class VII and VIII plasmids was assumed to be caused by the incompatibility function of Rep 2 of $\mathrm{pSK} 2^{*}$, since these plasmids retained the Rep 2 region (and the ability to pock normally against the plasmid-free strain) and lacked the $B g l \mathrm{II}(1)-\operatorname{SacI}(8)$ fragment. If they had Repl, they should have been released from the incompatibility effect of Rep 2 and would have formed regular pocks against the strain containing pSK2*. Indeed, the strain carrying D324 (class IV), which lacked the $B g l \mathrm{II}(1)-K p n I(6)$ fragment, induced regular pocks on a lawn of a strain carrying pSK2*. However, a strain carrying a D324 derivative with an insertion at the $B g l I I(9)$ site involving in Repl as described later, induced small pocks on a lawn of a strain carrying pSK2* and regular pocks on a lawn of a plasmid-free strain (data not shown). This implies that the $\operatorname{KpnI(6)-SacI(8)}$ region should be involved in Repl. Furthermore, the class V plasmid D312 was also suggested to be deficient in Repl besides Porl, since if it maintained a fully functional Repl, pSK $1^{*}$ should not induce regular pocks but small ones because of the incompatibility effect. Therefore, the $\operatorname{SacI}(8)-B g l \mathrm{II}(9)$ fragment in addition to the KpnI(6)-SacI(8) fragment and part of the $B g l$ II(9)-SacI(11) fragment should also be involved in the Repl function since the $B g / I I(9)-S a c I(11)$ fragment was involved in the pockforming determinant (Poc1) of the $\mathrm{pSK} 1^{*}$ part of $\mathrm{pSK} 3^{*}$ as mentioned before. From these results it was concluded that Repl should be located on the $\operatorname{KpnI}(6)-\operatorname{SacI}(11)$ fragment of the pSK $1^{*}$ part of pSK $3^{*}$. On the other hand, the small pock formation caused by pSK 2*-carrying strains against strains carrying class IV, VIII and IX plasmids could be explained by the incompatibility effect of Rep2 because these derivatives lacked the Por 2 region responsible for 
the full resistance to pSK2*. It was also of interest that the class IX plasmid (D3171) induced small pocks against the plasmid-free strain. Since the plasmid D3171 lacks Poc2 (Tra2), it must be transfered by Tral and replicated by Rep 2 to induce small pocks, because the transfer of D3171 was also associated with small pock formation as mentioned before. Therefore, Tral should be located on the $\operatorname{SacI}(11)-B g l I I(15)$ fragment. Furthermore, the explanation for the small pock formation by the class IX plasmid against plasmid-free strains will be that the $B g l$ II(9)-SacI(11) fragment, which is absent, is involved in Sprl (the function for plasmid spread of the pSK $1^{*}$ part of pSK $3^{*}$ ), necessary for the regular pock formation by the pSK $1^{*}$ part of pSK $3^{*}$. Based on these interpretations of results, the tentative locations of pSK $3^{*}$ functions involved in pock formation and pock resistance are summarized in Fig. 1.

\section{DISCUSSION}

$S$. kasugaensis MB273 harbours three species of plasmids: pSK1*, pSK2*, and their cointegrate pSK $3^{*}$. This cointegrate plasmid confers the pock-forming ability of $\mathrm{pSK} 1^{*}$ and pSK $2^{*}$ and pock resistance against pSK $1^{*}$ and pSK2* (Akagawa et al., 1987). As described in this report, pock-forming deletion derivatives of pSK $3^{*}$ which were constructed by in vitro recombination were analysed to identify DNA regions necessary for replication (Rep), pock formation (Poc) and pock resistance (Por) by assigning the deleted segments corresponding to phenotypic changes in pock formation and pock resistance. Subsequently, locations of two replication regions (Repl and Rep2), two pock-forming regions (Pocl and Poc2) consisting of the functions for plasmid transfer and spread (Tral/Sprl and Tra2/Spr2), and two pockresistance regions (Porl and Por2) corresponding to pSK $1^{*}$ and $\mathrm{pSK} 2^{*}$ were tentatively assigned (Fig. 1). The surmised location of Rep1 and Rep2, responsible for the incompatibility effect to pSK $1^{*}$ and $\mathrm{pSK} 2^{*}$, respectively, was in good agreement with that of Oril and Ori2 which were determined as regions necessary for replication and stability of pSK 1 and pSK 2 by Nabeshima et al. (1984). The plasmid D324, a deletion derivative of pSK $3 *$ (class IV), maintains both Repl and Rep2 regions thus determined. It was of special interest that both Rep1 and Rep2 were fully operative on the single replicon of the plasmid D324.

The regions for plasmid transfer were not clearly assigned due to the generation of small-pock variants by deletions involving this region. Induction of small pocks by the class IX deletion derivative of $\mathrm{pSK} 3^{*}$ (D3171) against a plasmid-free strain seemed to be due to a weak transfer activity of the plasmid since their formation could not be explained by the incompatibility effect alone. This could be explained by the hypothesis of 'spread' of plasmid copies within the recipient hyphae following an intermycelial transfer from donor to recipient [proposed by Kieser et al. (1982) to explain the properties of $\mathrm{pIJ} 101$ derivatives and by Lydiate $e$ t al. (1985) for SCP2*]. Attempts to identify any structures associated with mating between the parental hyphae were unsuccessful when pock areas were examined by scanning electron microscopy (data not shown). It seems reasonable to postulate that the function (Spr) for plasmid spread in addition to the function (Tra) for plasmid transfer are necessary for regular pock formation as in the cases of pIJ101 and SCP2*. Therefore, the BglII(9)-SacI(11) fragment adjacent to the Tral region (missing in D3171) was obviously necessary for regular pock formation and was regarded as the region for Spr1. The Spr2 region in Poc2 could also be located in some region adjacent to or overlapping Tra2, although no segment was assigned to Spr2 in this study. However, the $B c l$ I(23)-Bam HI(25) fragment should be included in the Tra2 region since attempts to construct pock-forming $\mathrm{pSK} 2^{*}$ derivatives with insertion at the $B c l \mathrm{I}(23)$ site or deletions of the Bam HI(24)-Bam HI(25) fragment were unsuccessful (Akagawa et al., 1984).

On the other hand, the regions of $\mathrm{pSK} 3^{*}$ conferring pock resistance on $S$. kasugaensis carrying pSK $3^{*}$ and its deletion derivatives were regarded as the functions for pock resistance (Porl against pSK $1^{*}$ and Por 2 against pSK2*). The location of Por 2 in the pSK2* part of pSK $3^{*}$ was assigned to a short DNA segment $(1.35 \mathrm{~kb})$ extending from the $K p n \mathrm{I}(26)$ site to the $\operatorname{Bam} \mathrm{HI}(2)$ site, which could encode one or two genes. This result suggests that only one or two genes are involved in the pock resistance determinant of the pSK2* part of pSK $3^{*}$. It has been reported that pIJ101 (Kieser et al., 1982), SLP1 (Bibb et al., 1981) and SCP2* (Lydiate et al., 1985) have 
'lethal-zygosis' resistance (pock resistance) to their own pock-forming activity. However, their locations have not yet been fully assigned. It was not determined in this study whether Por 2 was essential for Tra2 function. However, as indicated by plasmids D323 and pSK 1-2R3*, the Por2 region appeared to overlap the Tra2 region. The Porl region also overlaps Tra1 (Fig. 1). This is of special interest in the elucidation of their specific pock-resistance mechanisms to the pockforming activity of their own plasmid. It seems likely that Por regions are shorter than Tra regions. Therefore, whether or not specific sequences in Tra regions function as Por sequences will be an interesting question to be answered in the future.

Another interesting feature was that Rep, Poc (Tra/Spr) and Por seemed to be arranged in the same order in both the pSK $1^{*}$ and the pSK2* parts of pSK $3^{*}$. This might suggest some evolutionary relationship between $\mathrm{pSK} 1^{*}$ and $\mathrm{pSK} 2^{*}$.

The author deeply thanks Mrs Kazue Kawaguchi and Mrs Yukie Takano, NIHJ, for essential experimental assistance, Dr Masanosuke Yoshikawa, Institute of Medical Science, University of Tokyo, for helpful discussion on this study, and Dr Kunimoto Hotta, NIHJ, for helpful comments on the manuscript.

\section{REFERENCES}

akagawa, H., Kawaguchi, K. \& Ichihara, M. (1984). Plasmids of Streptomyces kasugaensis MB273: their pock formation, their dispensable endonuclease cleavage sites for pock formation, and transformation of S. kasugaensis MB273 by them. Journal of Antibiotics 37, 1016-1025.

akagawa, H., Takano, Y. \& KaWaguchi, K. (1987). Characterization of a natural cointegrate of the pock-forming plasmids pSK $1^{*}$ and $\mathrm{pSK} 2^{*}$ of Streptomyces kasugaensis MB273. Journal of General Microbiology 133, 1941-1949.

BIBB, M. J. \& HoPwOod, D. A. (1981). Genetic studies of the fertility plasmid SCP2 and its SCP2* variants in Streptomyces coelicolor A3(2). Journal of General Microbiology 126, 427-442.

Bibb, M. J., Freeman, R. F. \& Hopwood, D. A. (1977). Physical and genetical characterization of a second sex factor, SCP2, for Streptomyces coelicolor A3(2). Molecular and General Genetics 154, 155-166.
Bibb, M. J., Ward, J. M., Kieser, T., Cohen, S. N. \& HoPwOOD, D. A. (1981). Excision of chromosomal DNA sequences from Streptomyces coelicolor forms a novel family of plasmids detectable in Streptomyces lividans. Molecular and General Genetics 184, 230240.

KIESER, T., HoPWOOD, D. A., WRIGHT, H. M. \& ThOMPSON, C. J. (1982). plJ 101, a multi-copy broad host-range Streptomyces plasmid : functional analysis and development of DNA cloning vectors. Molecular and General Genetics 185, 223-238.

Lydiate, D. J., Malpartida, F. \& Hopwood, D. A. (1985). The Streptomyces plasmid SCP2*: its functional analysis and development into useful cloning vectors. Gene 35, 223-235.

Nabeshima, S., Hotta, Y. \& OKanishi, M. (1984). Construction of plasmid vectors from Streptomyces kasugaensis plasmids, pSK1 and pSK2. Journal of Antibiotics 37, 1026-1037. 